\title{
Volcanism and arthropods: a review
}

\author{
LUCIANA ELIZALDE \\ Laboratorio Ecotono, CRUB-Universidad Nacional del Comahue, INIBIOMA-CONICET, Bariloche, Argentina.
}

\begin{abstract}
Aвstract. Volcanic eruptions are natural disturbances that impose multiple changes in ecosystems. Arthropods are among the most diverse organisms on the planet and play key functional roles in all ecosystems. Existing information on the effects of volcanic disturbances on arthropods is scattered. The aim of this review is to find generalities in the responses of arthropods from terrestrial and aquatic environments to volcanism. Mainly (1) what effects do volcanic disturbances have on arthropods?, (2) what characteristics make certain species more or less susceptible to volcanic disturbances?, and (3) how do arthropod communities reassemble after a volcanic disturbance? Terrestrial and aquatic arthropods show similar responses to volcanic disturbances. Volcanism can affect arthropod populations, communities, and ecosystems through the functions that arthropods perform. Most studies evaluated the effect of volcanic ash as the primary volcanic disturbance type and found that most species have higher mortality than controls, but species show different susceptibility to volcanism. However, mortality of a certain species varies by the amount of ash, how the species was exposed to ash (i.e. body contact, contaminated food, modification of the habitat), and relative humidity. In the few arthropod communities studied, richness, composition and abundance of species are affected to some degree by volcanic eruptions. I gathered information on a number of morphological, physiological, behavioral and life-history traits that seem important to determine species responses to volcanic disturbance. However, current knowledge of arthropod responses to volcanism is limited, and limited to few volcanic eruptions. More broadly, studies of volcanic events may provide ecosystem-scale insights on how climate change and human-induced changes, such as higher concentration of particles in suspension or gas emission to the environment, might affect arthropod communities.
\end{abstract}

[Keywords: Disturbance, volcanic eruption, ash, Puyehue-Cordón Caulle, Mount St. Helens, insect, arachnid, crustacean, traits, density-independent mortality]

Resumen: Vulcanismo y artrópodos: una revisión: Las erupciones volcánicas son disturbios naturales que imponen múltiples cambios en los ecosistemas. Los artrópodos se ubican entre los organismos más diversos del planeta y desempeñan un papel clave en el funcionamiento de los ecosistemas. Sin embargo, la información existente sobre los efectos de los disturbios volcánicos sobre ellos es dispersa. El objetivo de esta revisión es identificar generalidades en las respuestas de los artrópodos al vulcanismo. Principalmente, (1) ¿qué efecto tienen las erupciones volcánicas sobre los artrópodos?, (2) ¿qué características hacen que ciertas especies sean más resistentes al vulcanismo?, (3) ¿cómo se ensamblan sus comunidades después de una erupción? Los artrópodos terrestres y acuáticos muestran respuestas similares al vulcanismo, que afecta a sus poblaciones y comunidades, y los ecosistemas a través de las funciones que los artrópodos realizan. La mayoría de los estudios que evaluaron el efecto de la ceniza volcánica encontraron efectos negativos sobre la mortalidad y diferente susceptibilidad entre especies. La mortalidad en una misma especie varía según la cantidad de ceniza y la forma de exposición (contacto con el cuerpo, alimentos contaminados, modificación del hábitat), y la humedad relativa. En las pocas comunidades de artrópodos donde se estudiaron los efectos de las erupciones volcánicas, la riqueza, composición y abundancia de las especies son afectadas de alguna forma. Identifiqué rasgos morfológicos, fisiológicos, comportamentales y de historia de vida que parecen importantes para determinar respuestas de las especies al vulcanismo. Sin embargo, los conocimientos actuales son limitados y acotados a pocas erupciones volcánicas. Los estudios de eventos volcánicos pueden proporcionar una validación a escala del ecosistema de las predicciones sobre cómo el cambio climático y los cambios inducidos por el hombre, como una mayor concentración de partículas en suspensión o de emisión de gases al ambiente, pueden afectar a las comunidades de artrópodos.

[Palabras clave: Disturbio, erupción volcánica, ceniza, Puyehue-Cordón Caulle, Monte Santa Helena, insectos, arácnidos, crustáceos, rasgos, mortalidad denso- independiente]

\section{INTRODUCTION}

Volcanic eruptions are natural disturbances that impose multiple changes on ecosystems (del Moral \& Grishin 1999; Ayris \& Delmelle 2012). A single eruption may include several distinct types of volcanic disturbance,

Editor invitado: Thomas Kitzberger

luciana.elizalde@crub.uncoma.edu.ar including lava flows, toxic gas emissions, pyroclastic density currents (fast-moving current of hot gas and rock that travel across the ground), tephra falls (deposition of airtransported volcanic material), and lahars (moving fluid masses composed of volcanic debris, mud, and water) (del Moral \& Grishin 
1999). Moreover, volcanism includes several mechanisms of disturbance that are sensed by the biota as heat, burial, abrasion, and impact force (Swanson et al. 2013). Collectively, this great variety of volcanic disturbance types, operating at differing intensities, and their associated mechanisms of disturbance result in a myriad of potential impact severities to arthropods. Typically, near the crater the intensity of the disturbance is the greatest, and decreases with distance from the volcano. Besides this intensity gradient for the same eruptive event, different eruptions release varying amounts of particulate and gaseous products into the atmosphere (Simkin \& Siebert 2002). Other properties that characterize ecological disturbances are the size of the disturbed area and frequency of occurrence (Sousa 1984). Some volcanic eruptions have global effects, mainly due to volcanic ash and aerosols that contain sulfur, chlorine and fluoride gasses. Fine ash particles are dispersed several thousand kilometers by wind, while larger particles settle closer to the volcano (Ayris \& Delmelle 2012). The frequency of volcanic disturbances that affect a given area may be high in some regions. In fact, fifteen volcanoes have been erupting more or less continuously through the last three decades, but most active volcanoes erupt in timeframes of decades or centuries (Simkin \& Siebert 2002), and are thus operating at ecologically relevant timescales given the time required for succession to proceed in many ecosystems. After the eruptive process, tephra remains in the environment for many years, and its remobilization can be a dominant feature of post-eruptive landscapes (Ayris \& Delmelle 2012). Finally, the effects of volcanic eruptions on the environment depend on the characteristics of the area, such as climate, substrate type, and landscape heterogeneity (del Moral \& Grishin 1999).

Arthropods (insects, spiders, mites, scorpions, millipedes, crustaceans) are the most diverse group of eukaryotes on the planet (Mora et al. 2011) and inhabit all ecosystems, where they play key functional roles. Arthropods contribute in nutrient cycling and constitute important links in aquatic and terrestrial food webs; they also promote diversity of plants by affecting pollination and seed dispersal (Price et al. 2011). A volcanic eruption can cause mortality and affect the habitat of arthropods, changing food sources, shelter, and microclimate conditions (del Moral \& Grishin
1999; Ayris \& Delmelle 2012). These changes may influence their survival, behavior, and reproduction. However, arthropods respond in different ways to disturbances (Schowalter 2012). Additionally, arthropods are ideal candidates to study how areas affected by a volcanic eruption recover as they are good bioindicators of environmental condition (Price et al. 2011). The existing information on the effect of volcanic disturbances on arthropods (i.e. the type, intensity, and severity of the disturbance) is scarce and scattered. Yet, there are a few iconic volcanoes that have provided many insights on arthropod responses to volcanism (e.g., Krakatoa, Surtsey, Mount St. Helens). Eruption events are unique opportunities to understand the mechanisms that influence contemporary ecosystems, as well as agents of change that have influenced biodiversity in past times. Hence, eruption sites make exemplary living laboratories to evaluate theories of ecological disturbance and subsequent recovery processes in biological communities (Veblen \& Ashton 1978; del Moral \& Grishin 1999).

The aim of this review is to make a critical appraisal of the existing literature in order to find generalities in the responses of arthropods from terrestrial and aquatic environments to volcanism. I will focus on the following questions: (1) what effect do volcanic disturbances have on arthropods?, (2) what characteristics make certain species more or less susceptible to volcanic disturbances?, and (3) how are arthropod communities restructured after volcanic disturbance? The first question focuses on the effects of volcanic eruptions in the short-term at different organizational levels, i.e., individual, population, community and ecosystem. Then I will group and discuss traits associated with the effects of volcanism on arthropods found in the literature, i.e. morphological, physiological, behavioral and life-history traits. Finally, I will focus on longer-term responses of arthropod communities to volcanic disturbances.

\section{EFFECTS OF VOLCANISM ON ARTHROPODS}

Volcanism can affect arthropod populations, communities, and ecosystems through the functions that they perform. To quantify the effects of volcanism on arthropods I included laboratory and field studies where the effect was compared with a control situation (e.g., 
bioassays with and without volcanic ash, areas affected by volcanic disturbance compared to undisturbed areas, pre and post disturbance data). These studies are summarized in Appendices 1 and 2 (Supplementary Information), for effects at population and community levels, respectively. Due to a limited amount of information published on the subject, I included publications based on semi-quantitative and observational data, and some of which do not use statistics to compare results.

Most studies evaluated the effect of volcanic ash (tephra particle size $<2 \mathrm{~mm}$ ) as the primary disturbance type (Appendices 1, 2). A 92.8\% of the studied species ( $n=14$ species) had higher mortality than controls when exposed to volcanic ash in the laboratory. However, mortality for the same species varied with the amount of ash in the experiment, how

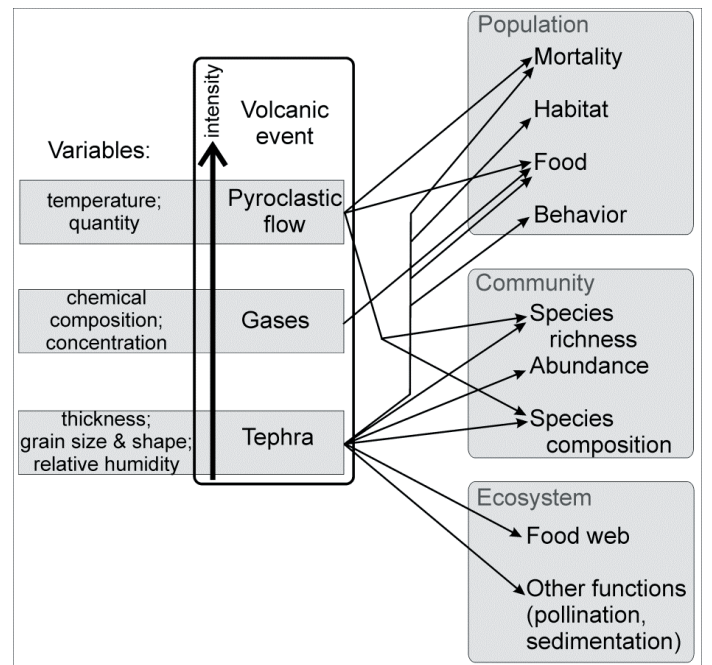

Figure 1. Volcanic disturbances reported in the literature to affect arthropods. Volcanic events are ordered according to increasing intensity (vertical arrow) and severity of arthropod impacts, and variables that affect that intensity/severity are identified. Thin arrows indicate reported effects that affect arthropods (more details in the text). The reader can think on many more arrows connecting these responses to volcanic disturbances, which gives an idea of the work that still needs to be done on the subject.

Figura 1. Perturbaciones volcánicas que afectan a los artrópodos reportadas en la literatura. Los eventos volcánicos se ordenan según intensidad creciente (flecha vertical) y la severidad de sus impactos sobre los artrópodos, y se identifican las variables que afectan a la intensidad/severidad. Las flechas finas indican las perturbaciones volcánicas reportadas en la literatura que afectan a los artrópodos (más detalles en el texto). El lector puede pensar en muchas más flechas que conectan estas respuestas a las perturbaciones volcánicas, lo que da una idea del trabajo que aún queda por realizar en el tema. it was exposed to ash, and relative humidity (Appendix 1). Field investigations report marked reductions in population size in $83.3 \%$ of the species studied ( $n=24$ species, Appendix 1). Whether a population is more or less susceptible to a volcanic event, depends on (1) external variables such as the type and intensity of the eruption (e.g., little ashfall, Akre et al. 1981), (2) particular traits of each species (Wille \& Fuentes 1975; Brown \& bin Hussain 1981), (3) timing of the eruption (e.g., in winter or rainy season the effect of the ash is reduced, susceptible stages are protected at the time oferuption, etc.; Howell 1981; Edwards \& Sugg 2005), and (4) effects on species with which arthropods interact (Wille \& Fuentes 1975; Martínez et al. 2013).

In the few arthropod communities where the effects of volcanic eruptions were studied, richness, composition and abundance of species were affected in some way (Appendix $2)$. Half of these studies $(n=6)$ found a decrease in species richness, while the other studies showed no change in richness. In terms of abundance, $80 \%$ of the work done showed a decrease (Appendix 2). In the following section, I also include results from studies that do not use a volcanically undisturbed reference site (control) situation if they add important information.

\section{Individual and population levels}

During an eruption, organisms that are closer to the vent are killed instantly by one or more mechanism such as extreme heat, abrasion, impact force, or volcanic gases (Figure 1) (Sikes \& Slowik 2010). Tephra can carry gases, and release of these gases can contaminate water, soil and plant surfaces (Ayris \& Delmelle 2012). There are no studies that directly evaluate the effect of volcanic gases on arthropods, although during the eruption of Kasatochi volcano, Alaska (KV), numerous dead flies were observed near the crater, presumably poisoned by gases (Sikes \& Slowik 2010).

Arthropods may be buried by pyroclastic and lava flows near a volcano (Figure 1). In fact, at Mount St. Helens, USA (MSH), arthropod populations near the crater were eliminated by pyroclastic density currents (Edwards \& Sugg 2005). More distant to the crater, however, tephra can cover large areas, burying arthropods in terrestrial and benthic aquatic environments (Brown \& Cutright 1981; 
Miserendino et al. 2012). Even after several years of an eruption, unstable tephra deposited in hills can bury arthropods and their habitat (Collier et al. 2002). Depending on thickness of the deposited tephra, and on the abilities of organisms to dig, not all will die.

Those arthropods that survive burial must face a radically changed environment, where much of their food is buried or covered with volcanic ash (Figure 1). Eating food contaminated with ash is harmful, and in some cases leads to death. Lepidopteran larvae fed on an ash-mixed diet showed noticeable damage in peritrophic membrane of the gut and jaws, but the effect was not lethal because the larvae molt these structures at each instar (Brown \& bin Hussain 1981). However, most adult weevils eating ash-contaminated leaves died within a week (Shanks \& Chase 1981). In vegetation covered with volcanic tephra a high concentration of fluoride may be detected, which can inflict mortality in herbivores that feed upon contaminated plants (see Ayris \& Delmelle 2012). Crustaceans of the genus Daphnia are nonselective filterfeeders of the zooplankton in freshwater lakes. When exposed to ash suspended in the water column, different amounts of ash were found in the gut, which was collapsed in Daphnia exposed to higher concentrations (Wolinski et al. 2013). Ingesting ash may be inadvertent and not always related to feeding. Crickets and cockroaches kept in containers with ash and clean food had a glutinous boli of ash throughout the gut, suggesting it was ingested while they were cleaning their bodies (Edwards \& Schwartz 1981).

Volcanic ash may occlude the respiratory structures causing gas-exchange stress (Figure 1). Under laboratory conditions, crickets and cockroaches exposed to ashes had spiracles occluded by particles (Edwards \& Schwartz 1981). However, the good spiracular valves of a grasshopper prevented ash from entering the respiratory sacs (Brown $\&$ bin Hussain 1981). In aquatic arthropods, ash deposited on the gills or other respiratory structures is also presumed to make breathing difficult (Gersich \& Brusven 1982). It is likely that respiratory stress is not a cause of death itself, but added to water and ionic imbalance, increases the susceptibility of arthropods exposed to ashes.

Volcanic ash produces behavioral changes in arthropods. Insects exposed to ash showed reduced mobility and feeding (Figure 1). This is because ash enters the articular membranes and increases friction of the moving parts, exacerbating abrasive effects (Brown \& bin Hussain 1981; Shanks \& Chase 1981). In addition, honeybees that failed to clean the ash from their body lost ability to fly (Brown \& bin Hussain 1981), and a decrease by $9 \%$ in overall mean number of flights was recorded when an ash cloud from a volcano, situated more than $2500 \mathrm{~km}$ away, was over the area (Woyke \& Gąbka 2011). Several stream insects of the orders Ephemeroptera, Plecoptera and Trichoptera preferred ashless substrates because the sealing effect of the deposited ash impedes staying fixed on the substrate (Brusven \& Horing 1984).

Also changes in aggressive behavior were detected. Decreased aggression was observed in honeybees, possibly due to a modification in their venom sac (Wille \& Fuentes 1975). However, bees from apiaries exposed to MSH ashfall showed highly aggressive behaviors (Johansen et al. 1981). A decrease in cannibalism, typical of a stonefly species, occurred in the presence of ash suspended in the water column that resulted in increased mortality in controls. This was explained by reduced visibility, conspecific avoidance and feeding inhibition under ash conditions (Brusven \& Horing 1984).

Nevertheless, desiccation is among the main mortality factor of terrestrial arthropods exposed to volcanic ash. Ash particles abrade the upper layers of the cuticle, which protects arthropods from water loss (Wille \& Fuentes 1975). The shape of the ash particle can be important because acicular grains may cause stronger desiccant effect than angular ones (Edwards \& Schwartz 1981). Mortality also varies by species, with some being quite tolerant to ash (Brown \& bin Hussain 1981, Appendix 1). Excess of salivation production used to clean and groom ash from the body can further increase water loss (Edwards \& Schwartz 1981).

Because of the importance of desiccation in ashinduced mortality, arthropods from mesic habitats would be less affected by the ash than those from xeric habitats. Although this hypothesis was not tested in the field, it was supported by laboratory experiments. Mortality caused by volcanic ash in grasshoppers and honeybees was higher for those insects maintained at lower relative humidity (Wille \& Fuentes 1975; Johansen et al. 1981). Ash-induced mortality in a grasshopper from a xeric habitat was not higher than at more humid conditions, but higher food intake was observed at low humidity suggesting that grasshoppers may obtain water from food (Fernández-Arhex et al. 2013). Nevertheless, arthropods from xeric habitats may have some adaptations that help them 
to tolerate better the effect of volcanic ash (see "Morphological traits"). At the other extreme, desiccation is not a problem for aquatic arthropods. However, the abrasive effect of volcanic ash on the cuticle may affect osmoregulation, altering the balance of salt and water, which is regulated by the cuticle (Miserendino et al. 2012). This may cause a physiological imbalance with a constant input of water and output of ions, ending with the death of the organism. However, this mechanism of mortality needs to be tested.

Another proposed mechanism implies absorption of cuticular waxes by ash particles (Wille \& Fuentes 1975; Buteler et al. 2011). While assays with honeybees suggest that this would not be important (Brown \& bin Hussain 1981), this mechanism requires further investigation. Inert powders, which act similarly to volcanic ash (Wille \& Fuentes 1975), adhere firmly to the body surface and absorb the wax layer of the cuticle, especially in insects that exhibit electrical charges (Stadler et al. 2010). It is also possible that acids released from ash when in contact with water, such as sulfuric acid, chemically attack the arthropod cuticle, as was shown for plants (Ayris \& Delmelle 2012), making them more susceptible to water imbalance. These effects have not been tested yet.

The severity of impact to arthropods is related to ash characteristics, such as grain shape as mentioned above, grain size, and deposit thickness (Figure 1). Populations of Vespula wasps were devastated when $3 \mathrm{~cm}$ or more of ash was deposited at the MSH (USA) and Puyehue-Cordón Caulle (PCCV, Argentina) volcanoes (Akre et al. 1981; Masciocchi et al. 2012). Meanwhile, thinner deposits may result in reduced population sizes (Akre et al. 1981; Masciocchi et al. 2012). This effect may be related to the inability of queens to emerge from their overwintering sites when buried by ash. In a lake, cladoceran population size and survival decreased with higher concentrations of suspended ash. However, small amounts of ash did not affect survival and resulted in turn in an increase in reproduction, probably associated with an increase in available phosphorous (Wolinski et al. 2013).

Particle size of the ash is important because smaller particles cause more damage than the coarser ones, similar to what happens with inert powders (Stadler et al. 2010). However, there is no experimental evidence with volcanic ash. Some evidence comes from MSH, where the coarser tephra that fell southeast of the volcano did not accumulate in flower baskets (Brown \& Cutright 1981), so honeybees did not forage on contaminated pollen. While in sites located to the east, where ash particles were finer, the damage caused by ash to bee colonies was more dramatic (Brown \& Cutright 1981).

\section{Community-level effects}

The effects of volcanic disturbance on arthropod species richness are evident in areas heavily affected by lava and pyroclastic flows (Figure 1). Changes in arthropod communities were recorded after the volcanic eruption in $\mathrm{KV}$, where insect richness decreased 9 fold (Sikes \& Slowik 2010). For ground-dwelling beetle assemblages, species composition in forests affected by the eruption of MSH was different from undisturbed reference forest areas 20 years post-eruption (only $5 \%$ or $30 \%$ of species shared in areas affected by pyroclastic flows and tephra, respectively). However, species richness was quite similar (Parmenter et al. 2005). After 43 years of the eruption of a volcano in an island in the Azores, species richness was higher in a site which received some ash from the volcanic eruption (moderately disturbed), although diversity indices were higher in undisturbed sites (Fattorini \& Borges 2012). Species composition was different among the most affected, the moderately disturbed and the undisturbed sites. In the area most affected by the eruption, where primary succession took place, the proportion of native species was lower compared with areas moderately or unaffected by the eruption. In fact, no endemic species was able to recolonize the erupted area (Fattorini \& Borges 2012). The post disturbance sequence in a stream affected by ashfall and riverbank alteration after the eruption of MSH showed a slow shift in stream macroinvertebrate community composition, with increases in sensitive taxa such as Ephemeroptera, Plecoptera, Trichoptera, and decreases in chironomid species (Meyerhoff 1991; Anderson 1992). At least 25 taxa of benthic macroinvertebrates were extirpated from rivers in Chubut, Argentina, after Chaitén volcano ashfall (Miserendino et al. 2012). These invertebrates did not reappear 2 years after the eruption. This effect was more related to changes in suspended ash concentration than to chemical changes. Moreover, the effect of ashfall was more dramatic in smaller rivers (Miserendino et al. 2012).

In general, arthropod abundance decreases after volcanic disturbance (Figure 1). Ash accumulated on leaves of a tropical forest after the eruption of Soufrière Hills $(\mathrm{SH})$, in Montserrat, had a significant negative effect on insect canopy abundance (43\%) (Marske et al. 2007). Psocoptera, Coleoptera, and Formicidae showed a significant negative 
response. However, abundance of some arthropods increased after a volcanic event, as was found in wheat fields for aphids and their predators (Klostermeyer et al. 1981). The increase of aphids might have been related to the elongated shape of wheat leaves which accumulate less ash than broadleaf plants (Klostermeyer et al. 1981).

An interesting way to study the effect of tephrafall from past volcanic events in lakes is through sediment analyses. A sub fossil chironomid community deposited in sediments from a lake affected by a tephrafall event from Llaima volcano (Chile), showed changes in abundance but not in species richness (Araneda et al. 2007). Around 5 years after the eruption, abundance of most chironomid species was similar to preeruption values (Araneda et al. 2007). An increase in abundance of some chironomid species was recorded in a lake immediately after the eruption of Mt. Mazama (USA). These chironomids were tolerant to the high salinity conditions that prevailed during that period (Heinrichs etal. 1999). At an extreme, all species from chironomid sub fossil assemblages were replaced in a Patagonian lake (Argentina) after intense Holocene volcanic eruptions (Corley \& Massaferro 1998).

\section{Ecosystem-level effects, mediated by arthropods}

Volcanic events have impacts on ecosystem functioning through changes in arthropod community structure (Figure 1). However, very little is known about these effects. Few studies evaluated the changes that occur in some links of food webs, where arthropods are essential components in aquatic and terrestrial environments. The alteration of food availability is thought to be the main factor that affected the density of an insectivorous bird after the eruption of SH (Marske et al. 2007). In addition, a change in an owl's diet may reflect the effect of MSH eruption on insect populations (Grimm et al. 1985). Arthropods were the major food items found in sub yearling Chinook salmon in streams around MSH (Kirn et al. 1986). After the eruption, there was a decreased consumption of amphipods and increased consumption of insects, mysids and cladocerans. However, changes occurred at the short-term because an increase of amphipod consumption was observed two years after the eruption (Kirn et al. 1986).
There is some evidence suggesting that pollination can be reduced on flowers covered with volcanic ash. For example, when flowers were sprayed with volcanic ash, the rate of visits by bees ceased altogether (Martínez et al. 2013). In that experiment, bees were offered flowers without ash, but in natural areas affected by ashfall all flowers have some degree of accumulated ash. However, some flowers may accumulate less ash, like those with downward facing corollas (Brown \& Cutright 1981).

Zooplankton crustaceans such as Daphnia, promote the sedimentation of suspended particles like volcanic ash. These particles are ingested and brought together while passing through the intestine, and later eliminated with feces. Indeed, sedimentation of ash was higher in containers with Daphnia juveniles than in control lab assays (Wolinski 2012).

\section{TRAITS THAT INFLUENCE ARTHROPOD RESPONSES TO VOLCANISM}

In this section I review some traits that are reported to or might influence the tolerance of arthropods to volcanic events or similar disturbances (Table 1). In the next section, I include other traits related to dispersal and colonization abilities of species (Table 1 ), important in community reassembly processes.

\section{Morphological traits}

Because physical abrasion of the cuticle by ash is among the main mechanisms causing arthropod mortality, all else being equal, arthropods with a thicker cuticle or with cuticle that rapidly reconstitutes will be less affected (Wille \& Fuentes 1975; Woodrow et al. 2000). Indeed, cuticle adaptations to live in a dusty environment may be important to tolerate ash abrasion, like curculionid beetles adapted to breed in stored grains that survived to ash exposure in contrast to other insects, such as houseflies and honeybees (Brown \& bin Hussain 1981). Some mealy bugs and scale insects are protected from ash by waxy secretions, which apparently contributed to the increase in populations detected after the eruption of the Irazú volcano (IV) (Wille \& Fuentes 1975). In addition, some arthropods that live in xeric habitats have adaptations that allow them to reduce water loss, such as a thicker cuticle and protected spiracles or 
with valves (Snodgrass 1935), suggesting that they could tolerate better the effect of volcanic ash compared to species or populations living in more mesic areas.

Sculpturing of the cuticle and cuticular structures may determine greater adhesion of ash particles. The high density of body hairs of some lepidopteran larvae seems to be one of the causes of the higher mortality of these insects compared to others (Mason et al. 1984). Higher adhesion of ash particles was found for cuticular structures, body armature and pubescence in stream insects (Gersich \& Brusven 1982). However, specific microstructures of the cuticle of some arthropods give them self-cleaning properties, by reducing the contact area between the particle and the body surface, as found in collembolans, a group of wingless arthropods common in the soil (Helbig et al. 2011), and the wings of insects (Wagner et al. 1996). This particular microstructure in the cuticle results in very low adhesive forces and allows quick removal of particles (Helbig et al. 2011). Only one study evaluates the effect of volcanic ash on Collembola (Sminthuridae), and found that its abundance increased after the eruption of MSH (Klostermeyer et al. 1981). While that work did not evaluate the causes of that higher abundance, they might be unaffected by ash due to the self-cleaning properties of their cuticle.
Other structures help protect respiratory and digestive systems of arthropods against deleterious ash affects. Spiracles protection (valves, hairs, etc.) may be important to prevent ash from entering the tracheal system or blocking spiracles (Edwards \& Schwartz 1981). Most insects have a peritrophic membrane, a film-like structure that separates food from the midgut tissue and protects it against food abrasion (Snodgrass 1935). However, this peritrophic membrane is absent in adult Hemiptera and Lepidoptera, and possibly other insects that feed on fluids (Snodgrass 1935).

Theoretically, body size should be an important factor because smaller species suffer more from water imbalance due to their higher surface/volume ratio (Wille \& Fuentes 1975). However, there are no studies testing this hypothesis, or other size related predictions regarding ash effect on arthropods.

\section{Physiological and behavioral traits}

Capacity to withstand extreme or highly variable temperatures would benefit arthropods living near an active volcano or that receive hot ash immediately after the eruption (Schowalter 2012). It would also help to tolerate temperature changes that often occur in the environment when covered with lava or ash (Ayris \& Delmelle 2012).

Table 1. Traits that allow higher tolerance to volcanic disturbances and faster colonization of affected areas by arthropods. The question mark indicates that no general pattern was found yet. When the pattern corresponds only to terrestrial communities, it is indicated by (ter); otherwise aquatic and terrestrial communities share the trait.

Tabla 1. Rasgos de los artrópodos que permiten una mayor tolerancia a las perturbaciones volcánicas y una colonización más rápida de las zonas afectadas. El signo de interrogación indica que aún no se ha encontrado un patrón general. Cuando el patrón se corresponde únicamente a las comunidades terrestres se indica con (ter); en caso contrario, comunidades acuáticas y terrestres comparten el rasgo.

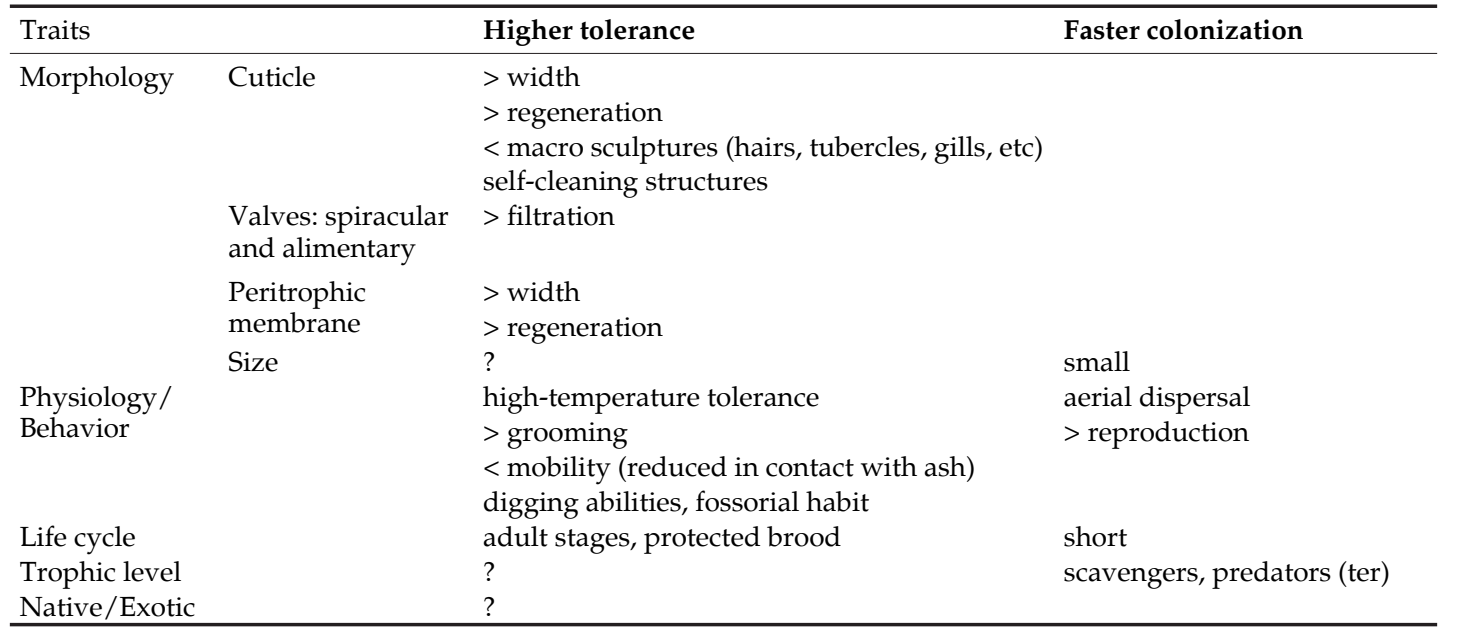


Many arthropods have efficient mechanisms to clean their body (Snodgrass 1935), which will help to remove ash quickly, and suffer less from abrasive effects. Social insects are the most notable example of the importance of grooming as a key factor in maintaining clean their colonies. When termite and ant colonies are sprayed with spores of fungal pathogens, they begin a series of cleaning behaviors among mates known as allgrooming (Rosengaus et al. 1998; Walker \& Hughes 2009). Also, nonsocial insects like the house crickets and cockroaches exposed to ash greatly increased self grooming (Edwards \& Schwartz 1981).

Living under the soil or having a fossorial habit may have favored many arthropods that avoided direct contact with the ash by being protected, as happened with pocket gophers and moles after the MSH eruption (Andersen \& MacMahon 1985). Alkali bees that nest in the soil (5-30 cm depth) were not largely affected by ashfall (Johansen et al. 1981), neither were soil nesting ants (Akre et al. 1981). However, populations of Vespula wasps that nest on the ground suffered more from volcanic ash than those that nested in the trees of the genus Dolichovespula (Akre et al. 1981). Therefore, it is possible that the difference is due to the abilities of each species to dig in volcanic ash rather than the habit of nesting in the soil itself.

\section{Life history stages affected}

In general, juveniles were more susceptible to the volcanic ash than adults (Howell 1981; Edwards \& Schwartz 1981). However, many arthropods have their immature stages protected from the ash in the soil like several beetles, within colonies such asocial insects, or protected by the epidermis of the leaves like leaf-miner larvae (Wille \& Fuentes 1975), or by cocoons like the wax moth larvae, that were spun when in contact with ash (Brown \& bin Hussain 1981). This variation in sensitivity to the disturbance of the different stages is important in the recovery of the affected populations. For example, the establishment and survival of caddisfly larvae was the limiting factor rather than the inability of adults to reach a site altered by volcanic ash (Anderson 1992).

This stage-dependent sensitivity might have a greater impact on populations of species with a single generation that reproduce once per year, compared to species with overlapping generations. For example, in annual species such as Vespula wasps the critical timing is when the young queens establish their new nests (Akre et al. 1981). At that time, all queens of the population are most vulnerable because colony establishment is critical to survival. When MSH erupted, the species of Vespula that were in the critical phase suffered more from the disturbance than other Vespula species that had already found their nests (Akre et al. 1981). Perennial organisms, such as ants, did not have this critical period and were not affected by volcanic ash (Akre et al. 1981).

\section{Trophic level}

Although herbivore adults of curculionid with root feeding larvae were completely eliminated from blueberry fields once exposed to MSH ash (Shanks \& Chase 1981), the herbivores that attack crops were not noticeably affected by ashfall from IV (Wille \& Fuentes 1975) nor from MSH (Klostermeyer et al. 1981). Some of them even increased their populations and became major pests, possibly helped by a reduction in their natural enemy populations, mainly parasitoids (Wille \& Fuentes 1975). Although, that negative effect of ash on parasitoids has not been adequately quantified, evidence from studies with inert powders showed that they were much more sensitive than the host (Perez-Mendoza et al. 1999). Other parasitoids of herbivorous insects were completely eliminated, together with their hosts, after the eruption in KV (Sikes \& Slowik 2010). However, kelp flies and their parasitoids were among the first organisms to colonize the island. In fact, a year after the eruption, the pre-eruption plant-based food web shifted to a necromass-based foodweb, subsisting on rotting kelp, guano, and carcasses (Sikes \& Slowik 2010). Finally, changes in beetle trophic structures along a disturbance gradient, during a 20 year post eruption timeframe, corresponded well with predicted patterns based on the availability of food resources in each zone (Parmenter et al. 2005, see below). Thus, these examples show that more than trophic level itself, generalization of the effect depends more on availability of food, which in turn depends on the community and type of disturbance.

\section{Native or exotic}

Adaptation by arthropods to volcanism per se is unlikely, given the low frequency of this disturbance relative to arthropod generation 
times (Schowalter 2012). However, in some volcanic areas with intense and recurrent disturbance (tens-hundreds of years) there might be adaptations of native species to volcanism. This is particularly so with disturbances related to volcanic tephra, due to the large areas that it covers and its permanence in the environment for several years after the eruption (Ayris \& Delmelle 2012). Then, it can be hypothesized that exotic species are more susceptible to volcanism than native species. After the eruption of PCCV two exotic Hymenoptera, Vespula wasps and the honeybee, suffered significant declines in their populations, and were even locally extirpated in some areas (Masciocchi et al. 2012; Martínez et al. 2013). However, in its native habitat Vespula also showed a local extinction with similar amounts of ash (Akre et al. 1981). The same was observed for other native Hymenoptera, the mason bees (Johansen et al. 1981). However, native alkali bees were more tolerant to the ash (Johansen et al. 1981). So far there is no clear evidence that this is an important trait affecting susceptibility to volcanic disturbance. However, these types of comparisons are often difficult to control because among the many native species present in a community some will be sensitive to disturbance. In addition, exotic species usually have high colonizing abilities. So while they might be strongly affected by the disturbance initially, they may be able to recover very quickly. Indeed, four species of exotic spiders were among the first colonizers of new pyroclastic flow surfaces at MSH (Crawford et al. 1995), as well as introduced insects in a volcanic island in the Azores (Fattorini \& Borges 2012).

In this section, I identified several morphological, physiological, behavioral, and life history traits that seem important to determine arthropod responses to volcanic events. Since certain aspects of the morphology and behavior are often shared by members of the same taxonomic group, some taxa may be more or less resistant to volcanic disturbance. However, species from the same genus may differ in a key trait, making them respond to volcanic disturbances in completely different ways. Thus, caution should be exerted when making generalizations at higher taxonomic levels. Furthermore, because species are a combination of traits, some of which may favor tolerance and others susceptibility to volcanic disturbances, it is necessary to gather as much empirical information as possible before using this approach for arthropod response prediction. Based on the response of particular species to eruptions and evaluation of their traits it will be possible to disentangle which traits or combination of them make species more or less tolerant and also which traits are more important to predict tolerance levels. In addition, it would be possible that arthropod species have preadaptations to other disturbances that allow them to tolerate better volcanism-related disturbances, as happens with plants (Turner et al. 1997). This seems to be the case for the so called lavicolous species, which are found on barren lava. These species are pre-adapted to the volcanic terrain (Ashmole et al. 1992; Fattorini \& Borges 2012), and are predators or detritivores eating organic material fallout, which cannot compete for resources or avoid predation when more species are present in the communities (Ashmole et al. 1992).

\section{COMMUNITY REASSEMBLY AND RECOVERY}

Primary succession in areas where life has been completely removed by volcanism such as happens in lava flows, pumice plains, and most lahars or on volcanic islands that emerged from the sea have been reviewed, including some information on arthropods (Bush \& Whittaker 1991; New 2008, and references therein). Secondary succession occurs most frequently on thin tephra and some lahars, because some biota or soil may survive (del Moral \& Grishin 1999). However, the gradient in the deposition of tephra blurs the distinction between primary and secondary succession (del Moral \& Grishin 1999). So, here I will focus on general patterns, and in the traits that may help to predict recolonization and reassembly of arthropod communities in areas affected by volcanic disturbance.

Recovery phases and assembly of new communities in terrestrial and aquatic environments affected by volcanic eruptions, seem to follow similar patterns as in areas affected by other disturbances (Anderson 1992; Collier et al. 2002; Hodkinson et al. 2002). Research on aerial plankton fallout after the eruption of MSH demonstrated that arthropod predators and scavengers were the first to colonize and establish in barren areas covered by pyroclastic flows, well in advance of pioneer plant species (Edwards 
1986; Edwards \& Sugg 2005; Sikes \& Slowik 2010). The same pattern was documented in Anak Krakatoa (New 2008) and in Motmot, Papua New Guinea (Edwards \& Thornton 2001), two small islands that emerged from the water after volcanic eruptions. In Surtsey, Iceland, an island that emerged from the sea after a volcanic eruption in 1963, the terrestrial arthropod community was composed of only three species after 12 years, all associated with littoral carcasses (New 2008). Secondary consumers preceding primary consumers in the successional process is a general pattern in most terrestrial denuded areas, reflecting the nature of the available food sources (Hodkinson et al. 2002). The predators, mainly spiders, beetles, and flies are able to maintain high numbers by feeding on windblown prey items, and the detritivores such as Collembola and Dermaptera feed on dead allochthonous organic materials (Crawford et al. 1995; Hodkinson et al. 2002; Edwards \& Sugg 2005). In this way, they contribute in capturing and concentrating nutrients, facilitating colonization by other organisms (Hodkinson et al. 2002; Edwards \& Sugg 2005).

Also in aquatic environments aerial dispersal, together with contributions from tributaries, favor the recolonization of streams and rivers after being affected by volcanic events (Anderson 1992; Collier et al. 2002). Chironomids, which have an adult flying dispersal stage, are overwhelmingly dominant in the recovery sequence among the arthropods after disturbances, and volcanic eruptions are not an exception (Anderson 1992; Collier et al. 2002). After the MSH eruption, chironomids accounted for $42 \%$ of the taxa at a stream and $80-90 \%$ of the biomass of all invertebrates collected in eight years after the eruption (Anderson 1992). While the number of chironomid taxa increased up to two years after volcanic disturbance, their dominance decreased from $75 \%$ in the year of eruption to $30 \%$ nine years after. The number of Ephemeroptera, Plecoptera, and Trichoptera taxa increased steadily from 3 to 50 in the same period after disturbance (Meyerhoff 1991; Anderson 1992). However, recovery times also depend on community characteristics. For example, macroinvertebrate densities and composition in a river directly affected by volcanism from the Redoubt Volcano, Alaska, was not significantly different from a nearby non-disturbed river only after 5 years of eruption (Dorava \& Milner 1999). This is a particular community, because the river is glacier-fed and its biota might be preadapted to high concentrations of particles in suspension (Dorava \& Milner 1999).

Besides the ability for aerial dispersal, other species traits were important at the community reassembly stage. Colonization by air was even faster if the species had short life cycle. In a river in New Zealand, after receiving an acidic lahar from $\mathrm{Mt}$ Ruapehu, midges and small caddisflies with small mobile adults and rapid life-cycles, recolonized the stream in large numbers within two weeks of the disturbance, and were able to dominate invertebrate communities for extended periods during the recovery process (Collier et al. 2002). Mayflies were slower to recolonize because they are weaker fliers than caddisflies (Collier et al. 2002). For non-flying aquatic invertebrates, recovery rates partly depended on how quickly they reproduce. A freshwater crayfish inhabiting streams in New Zealand, reproduce slowly and it took almost three years to recover after a land slip greatly affected the stream characteristics. Meanwhile a fast reproducing snail was well established after a year since the disturbance (Collier et al. 2002).

Many terrestrial arthropods have the ability to colonize by water, rafting on logs or directly on the water surface. Termite fauna in Krakatoa volcanic islands have only log nesting species, but lack ground-nesting termites, indicating that they have reached the islands by rafting on logs (New 2008). The same mechanism can be used by some arthropods to reach sites downstream, thus colonizing and establishing in an affected area. Wingless collembolans may colonize areas affected by a volcanic eruption by riding on floating tussocks, as was noted in Surtsey island (Bödvarsson 1982). Interestingly, collembolans might disperse by floating directly on the water surface, as was reported for two species inhabiting Surtsey (Bödvarsson 1982).

Once the pioneer plants are established in sites affected by a volcanic eruption, the arthropods may influence how plants colonize the area. Prairie lupine is a nitrogen-fixing legume that was the first plant to successfully colonize pyroclastic flow in MSH (Bishop et al. 2005). Herbivory on this legume by several lepidopteran larvae was very strong. Because prairie lupine has important effects on soil 
functioning and community development on the area, lepidopteran herbivory on this legume may have altered the pace and pattern of succession (Bishop et al. 2005). Generalist arthropod predators might slow down succession as suggested for the arthropod fauna from Motmot island, in Papua New Guinea, where after several decades of the volcanic eruption and the appearance of some vegetation the arthropod community remains in an early successional stage, with low species diversity due to the dominance of a generalist ant predator (Edwards \& Thornton 2001).

As mentioned above, the success of any population existing in an area depends upon finding food resources. Thus, it is important to consider community reassembly from a functional-role perspective. This was done for the trophic structures of ground-dwelling beetle assemblages after MSH eruption, where variation in trophic groups in a disturbance gradient corresponded well with predicted patterns based on the availability of food resources (Parmenter et al. 2005). Undisturbed natural forests are dominated by beetle predators, with herbivores, omnivores, and scavengers having lower diversity. The blow down forest, near the crater where many trees were knocked down by the eruption, was dominated by fungivorous beetles for many years after disturbance, apparently because of the high availability of decomposing log with abundant fungi (Parmenter et al. 2005). The pyroclastic flow immediately in front of the crater was dominated by predators, but showed an increase in herbivores and omnivores after 20 years post eruption, which parallels an increase in colonization by herbaceous vegetation during the same temporal frame. Beetle species that were abundant six years after the eruption on Pumice Plain and the blow down zone, were absent or greatly reduced in number 20 years after the eruption. This was interpreted as relay succession, where species replace others in the successional stages after a disturbance (Parmenter et al. 2005).

In sum, community recovery times varied from few to several years after the volcanic disturbance, depending on degree of habitat alteration (e.g. primary vs. secondary succession), distance from source populations, available food resources, and community characteristics. Arthropod community recovery may influence the colonization by organisms, including other arthropods, due to nutrient concentration and primary or secondary consumption. Table 1 summarizes some traits present in species that were early colonists and contribute to the initial recovery stages after volcanic disturbances.

\section{HOW MUCH DO WE KNOW?}

Most information about arthropod responses to volcanism had been generated after the eruption of MSH and recently for PCCV (Appendices 1 and 2). The effects of volcanic eruptions on arthropods have been studied for seven eruptions (Appendices 1 and 2), and if recolonization studies in Anak Krakatoa and Surtsey (New 2008) as well as studies from lake sediments mentioned above are included, it adds another seven volcanic events. Given that there are around 160 eruptions per decade (Simkin \& Siebert 2002), our knowledge of volcanic effect on arthropods seems very scarce and biased towards few volcanic events. Since each eruption has unique properties, it is essential to study more eruptions in order to have a more complete understanding of their effects on arthropods.

\section{CONCLUSIONS}

The first step towards developing generality in disturbance ecology is to find patterns in the diverse cases, reducing complexity and helping to develop further hypotheses (White \& Jentsch 2001). Volcanic events affected in similar ways terrestrial and aquatic arthropods, in contrast to other disturbances such as fire, hurricanes, and floods. Modification of the habitat, reduction in food availability and cuticle abrasion were the most important effects. These effects cause a decrease in the abundance of arthropod populations and, to a lesser extent, affect the species richness and composition, and ultimately, modify arthropods functional roles in ecosystems. Variation in these effects were related to different types and intensities of the disturbance (e.g. ashfall caused less radical effects than pyroclastic flows near the volcano) and the differential susceptibility of species. Even species within a single taxon may respond very differently, highlighting the need to obtain detailed taxonomic information from community-level studies instead of using higher taxa as surrogates (e.g., order or family) at this stage of knowledge. Current knowledge about arthropod responses to 
volcanic disturbances is limited, which restricts the validity of these generalizations. Many physiological mechanisms of the effect of ash are still speculative, and responses of several groups are not adequately quantified. In addition, this review highlights the need for well-controlled field studies at community level and for ecosystem processes mediated by arthropods. One of the main limitations of field studies is the lack of pre-eruption data to assess the effect of the disturbance. At present, many volcanic eruptions can be predicted within several months in advance, making possible to characterize the preeruption fauna.

Several studies emphasize the need to focus on a suite of traits associated with tolerance and recovery from disturbance that can be used to predict disturbance effects on diversity (Townsend et al. 1997; Davies \& Margules 2000; Haddad et al. 2008; Williams et al. 2010). Looking for consistent responses within groups that share traits would help to predict general patterns that could be applied to a wider range of taxa (Henle et al. 2004). Here I gathered and identified a number of traits that seem important to determine species responses to volcanic disturbances. It is still necessary to have more information on traits and species responses to test the ambiguous predictions generated by some traits. Certain traits (such as the presence of peritrophic membrane) may not be easy to assess, but that information may be obtained from published data. This approach, in addition to the use of bioindicator species, will provide stronger inference on the effects of volcanic disturbances, and perhaps other forms of disturbance to arthropods.

Studies of volcanic events can provide ecosystem-scale validation of predictions to climate change, such as higher $\mathrm{CO}_{2}$ concentration in the sea (Hall-Spencer et al. 2008). We can also learn from volcanic disturbances how human-induced changes, such as higher concentration of particles in suspension or gas emission to the environment, might affect arthropod communities. From another perspective, understanding arthropod responses to volcanic eruptions may provide insights for nature-inspired solutions to problems related to the impacts that volcanic ashes and other volcanic products have on human-built structures (Dingwell et al. 2012). Hence, a good understanding of the effect of volcanic disturbances on arthropods and their responses will help to broaden the theoretical framework of ecological disturbances and will help to resolve practical problems.

Acknowledgments. Thanks to G Pirk for suggesting the idea to write this review, and A Ruggiero and T Kitzberger for the invitation to participate in this special issue. D Meier, G Pirk, C Crisafulli, and two anonymous reviewers made valuable comments on different versions of this article to improve its quality. The author is postdoctoral fellow from Fundación Bunge y Born (Argentina).

\section{REFERENCES}

AKRe, RG; LD Hansen; HC ReEd \& LD CoRpus. 1981. Effects of ash from Mt. St. Helens on ants and yellow jackets. Melanderia, 37:3-19.

ANDERSON, NH. 1992. Influence of disturbance on insect communities in Pacific Northwest streams. Hydrobiologia, 248:79-92.

Araneda, A; F Cruces; L Torres \& S Bertrand. 2007. Changes of sub-fossil chironomid assemblages associated with volcanic sediment deposition in an Andean lake $\left(38^{\circ} \mathrm{S}\right)$, Chile. Rev. Chil. Hist. Nat., 80: 141-156.

Ashmole, N; P Oromí; M Ashmole \& J Matin. 1992. Primary faunal succession in volcanic terrain: lava and cave studies on the Canary Islands. Biol. J. Linn. Soc., 46:201-234

Ayris, PM \& P Delmelle. 2012. The immediate environmental effects of tephra emission. B Volcanol., 74:1905-1936.

Bishop, JG; WF Fagan; JD Schade \& CM CRisafulli. 2005. Causes and consequences of herbivory on prairie lupine (Lupinus lepidus) in early primary succession. Chapter 11. In: Dale, VH; FJ Swanson \& CM Crisafulli (eds). Ecological Responses to the 1980 Eruption of Mount St. Helens. Springer-Verlag, pp. 151-161.

BöDvarsson, H. 1982 The Collembola of Surtsey, Iceland. Surtsey Res. Prog. Rep., 9:63-67.

Brown, JJ \& W Cutright. 1981. Contamination of beecollected pollen with volcanic ash from Mount St. Helens. Melanderia, 37:39-44.

Brown, JJ \& Y BIN Hussain. 1981. Physiological effects of volcanic ash upon selected insects in the laboratory. Melanderia, 37:32-38.

Brusven, MA \& CE Horing. 1984. Effect of suspended and deposited volcanic ash on survival and behavior of stream insects. J. Kans. Entomol. Soc., 57:55-62.

Bush, MB \& RJ WhitTAKer. 1991. Krakatau: colonization patterns and hierarchies. J. Biogeogr., 18:341-356.

Buteler, M;T Stadler; GP López Garcñia; MS Lassa; D Trombotto Liaudat; PD Adamo \& V Fernandez-Arhex. 2011. Propiedades insecticidas de la ceniza del complejo volcánico Puyehue-Cordón Caulle y su posible impacto ambiental. Rev Soc Entomol. Argent., 70:149-156.

COLLIER, K; J QuinN \& M SCARSBROOK. 2002. Bouncing back: how fast can stream invertebrates recolonise? Water $\mathcal{E}$ Atmosphere, 10:9-11.

CORLEY, JC \& J MASSAFERRO. 1998 Long term turnover of a fossil community of chironomids (Diptera) from Lake Mascardi (Patagonia, Argentina). J. Kans. Entomol. Soc., 71:407-413. 
CRAWFORd, RL; PM SugG \& JS EdWARDS. 1995. Spider arrival and primary establishment on terrain depopulated by volcanic eruption at Mount St. Helens, Washington. Am. Midl. Nat., 133:60-75.

DAVIES, KF \&C MARGULES. 2000. Which traits of species predict population declines in experimental forest fragments? Ecology, 81:1450-1461.

Dingwell, DB; Y LaVAllée \& U Kueppers. 2012. Volcanic ash: A primary agent in the Earth system. Phys. Chem. Earth., 45-46:2-4.

Dorava, J \& A MiLnER. 1999. Effects of recent volcanic eruptions on aquatic habitat in the Drift River, Alaska, USA: Implications at other Cook Inlet Region volcanoes. Environ. Manage., 23:217-230.

EDWARDS, JS. 1986. Arthtopods as pioneers: recolonization of the blast zone on Mt St Helens Blast. Northwest Environ. J., 2:63-73.

EDWARDS, JS \& LM ScHWARTZ. 1981. Mount St. Helens ash: a natural insecticide. Can J Zool., 59:714-715.

EDWARDS, JS \& PM SUGg. 2005. Arthropods as pioneers in the regeneration of life on the pyroclastic-flow deposits of Mount St. Helens. Chapter 9. In: Dale, VH; FJ Swanson \& CM Crisafulli (eds). Ecological Responses to the 1980 Eruption of Mount St . Helens. Springer-Verlag, pp. 127-138.

EDWARDS, JS \& IWB THORNTON. 2001. Colonization of an island volcano, Long Island, Papua New Guinea, and an emergent island, Motmot, in its caldera lake. VI. The pioneer arthropod community of Motmot. J. Biogeogr., 28: 1379-1388.

FAttorini, S \& PAV Borges. 2012. Biogeographical kinetics on an island volcano (Capelinhos, Azores): fast colonisation rates and dominance of arthropod exotic species. Insect Conserv. Diver., 5:358-366.

FernÁndeZ-Arhex, V; M Buteler; ME Amadio; A EnriQuez; T STADLER; G BECKER \& O BRUZZONE. 2013. The effects of volcanic ash from Puyehue-Caulle range eruption on the survival of Dichroplus vittigerum (Orthoptera: Acrididae). Fla. Entomol., 96:286-288.

Gersich, FM \& MA Brusven. 1982. Volcanic ash accumulation and ash-voiding mechanisms of aquatic insects. J Kans Entomol Soc,55: 290-296.

GRIMM, DM; JT RATTI \&R FRIESZ. 1985. Effects of volcanic ash on food habits of burrowing owls at Moses Lake, Washington. Northwest Sci., 59:40-44.

Haddad, NM; M HolyoaK; TM Mata; KF Davies; BA Melbourne \& K Preston. 2008. Species' traits predict the effects of disturbance and productivity on diversity. Ecol. Lett., 11:348-356.

Hall-Spencer, JM; R Rodolfo-Metalpa; S Martin; E RANSOME; M Fine; SM TuRner; SJ Rowley; D Tedesco \& MC BuiA. 2008. Volcanic carbon dioxide vents show ecosystem effects of ocean acidification. Nature, 454: 96-99.

HeInRICHS, ML; IR WALKer; RW Mathewes \& RJ HebDa. 1999. Holocene chironomid-inferred salinity and paleovegetation reconstruction from Kilpoola Lake, British Columbia. Geogr. Phys. Quatern., 53:211-221.

Helbig, R; J Nickerl; C Neinhuis \& C Werner. 2011. Smart skin patterns protect springtails. PLOS ONE, 6:e25105.

Henle, K, KF Davies; M Kleyer; CMargules \&J Settele. 2004. Predictors of species sensitivity to fragmentation. Biodivers. Conserv., 13:207-251.

Hodkinson, I D; NR Webb \& SJ Coulson. 2002. Primary community assembly on land - the missing stages: why are the heterotrophic organisms always there first? J. Ecol., 90:569-577.

HowELL, JF. 1981. Codling moth; the effects of volcanic ash from the eruption of Mt. St. Helens on egg, larval, and adult survival. Melanderia,37: 50-55.

Johansen, CA; JD Eves; DF Mayer; JC BaCH; ME Nedrow \& CW Kious. 1981. Effects of ash from Mt. St. Helens on bees. Melanderia, 37:22-29.

KIRN, RA; RO LedgerwoOd \& AL Jensen. 1986. Diet of subyearling chinook salmon (Oncorhynchus tshawytsch) in the river estuary and changes effected by the 1980 eruption of Mount St . Helens. Northwest Sci., 60:191196.

Klostermeyer, EC; LD Corpus \& CL Campbell. 1981. Population changes in arthropods in wheat following volcanic ash fallout. Melanderia, 37:47-49.

MarsKe, KA; MA Ivie \& GM Hilton. 2007. Effects of volcanic ash on the forest canopy insects of Montserrat, West Indies. Environ. Entomol., 36:817-825.

Martínez, AS; M Masciocchi; JM Villacide; G Huerta; L DAneri; A BruchHausen; G Rozas \& JC Corley. 2013. Ashes in the air: the effects of volcanic ash emissions on plant-pollinator relationships and possible consequences for apiculture. Apidologie, 44: 268-277.

Masciocchi, M; AJ Pereira; MV Lantschner \& JC Corley. 2012. Of volcanoes and insects: the impact of the Puyehue-Cordón Caulle ash fall on populations of invasive social wasps, Vespula spp. Ecol. Res., 28:199205.

Mason, RR; BE Wickman\& HG Paul. 1984. The effect of ash from Mount St. Helens on survival of neonate larvae of the Douglas-fir tussock moth (Lepidoptera: Lymantriidae). Can. Entomol., 116:1145-1147.

MEYERHOFF, RD. 1991.Post-eruption recovery and secondary production of grazing insects in two streams near Mt. St. Helens. PhD thesis. Oregon State University.

Miserendino, ML; M Archangelsky; C Brand \& LB Epele. 2012. Environmental changes and macroinvertebrate responses in Patagonian streams (Argentina) to ashfall from the Chaitén Volcano (May 2008). Sci. Total Environ., 424:202-212.

MorA, C; DP TitTEnSOR; S AdL; AGB Simpson \& B Worm. 2011. How many species are there on Earth and in the ocean?. PLoS Biology, 9:e1001127.

DEL MORAL, R \& SY GRISHIN. 1999. Volcanic disturbances and ecosystem recovery. Chapter 5. In: L.R. Walker(ed) Ecosystems of disturbed ground. Elsevier. pp. 137-160.

NEW, TR. 2008. Insect conservation in early succession on islands: lessons from Surtsey, Iceland, and the Krakatau Archipelago, Indonesia. In: New, TR. (ed) Insect conservation and islands. Springer. pp. 113-118.

Parmenter, RR; CM CRISAFulli; NC Korbe; GL Parsons; MJ Kreutzian \& JA MacMahon. 2005. Posteruption arthropod auccession on the Mount St. Helens Volcano: the ground-dwelling beetle fauna (Coleoptera). Chapter 10. In: Dale, VH; FJ Swanson \& CM Crisafulli (eds). Ecological Responses to the 1980 Eruption of Mount St . Helens. Springer-Verlag, pp. 139-150.

Perez-MendozA, J; JE BaKer; FH Arthur \& PW Flinn.1999. Effects of Protect-It on efficacy of Anisopteromalus calandrae (Hymenoptera: Pteromalidae) parasitizing rice weevils (Coleoptera: Curculionidae) in wheat. Environ. Entomol., 28:529-534.

PRICE, PW; RF DenNo; MD EubanKs; DL FinKe \& I KaPlan. 2011. Insect ecology: Behavior, populations and communities. Cambridge University Press, New York. 
Rosengaus, RB; AB Maxmen; LE Coates \& JFA Traniello. 1998. Disease resistance: a benefit of sociality in the dampwood termite Zootermopsis angusticollis (Isoptera: Termopsidae). Behav. Ecol. Sociobiol., 44:125-134.

SCHOWALTER, TD. 2012. Insect responses to major landscapelevel disturbance. Annu. Rev. Entomol., 57:1-20.

SHANKS, CH \& DL CHASE. 1981. Effect of volcanic ash on adult Otiorhynchus (Coleoptera: Curculionidae). Melanderia, 37:63-66.

SIKES, DS \& J SLOWIK. 2010. Terrestrial arthropods of preand post-eruption Kasatochi Island, Alaska, 2008-2009: a shift from a plant-based to a necromass-based food web. Arct Antarct. Alp. Res., 42:297-305.

SIMKIN, T \& L SIEBERT. 2002. Global volcanism program. http:/ / www.volcano.si.edu

SNOdGrass, RE. 1935. Principles of insect morphology. McGraw-Hill Company.

SousA, WP. 1984. The role of disturbance in natural communities. Annu. Rev. Ecol. Syst., 15: 353-391.

Stadler, T; M Buteler \& DK Weaver. 2010. Nanoinsecticidas: Nuevas perspectivas para el control de plagas. Rev Soc Entomol Argent, 69:149-156.

SWANSON, FJ; JA JONES; CM CRISAFUlLi \& A LARA. 2013. Effects of volcanic and hydrologic processes on forest vegetation: Chaitén Volcano, Chile. Andean Geol., 40:359-391.

TownSEND, CR; S Doledec \& M Scarsbrook. 1997. Species traits in relation to temporal and spatial heterogeneity in streams: a test of habitat templet theory. Freshw. Biol., 37:367-387.

Turner, MG; VH Dale \& EH Everham. 1997. Fires, hurricanes, and volcanoes: comparing large disturbances. BioScience, 47:758-768.

VeBLEN, TT \& DH Ashton. 1978. Catastrophic influences on the vegetation of the Valdivian Andes, Chile. Vegetatio, 36:149-167.

WAGNER, T; C NeINHUIS \& W BARTHLOTT. 1996. Wettability and contaminability of insect wings as a function of their surface sculptures. Acta Zool., 77:213-225.

WAlker, TN \& WOH Hughes. 2009. Adaptive social immunity in leaf-cutting ants. Biol. Lett., 5:446-448.

White, PS \& A Jentsch.2001. The search for generality in studies of disturbance and ecosystem dynamics. Prog. Bot., 62:399-450.

WiLLE, A \& G FuENTES. 1975. Efecto de la ceniza del Volcán: Irazú (Costa Rica) en algunos insectos. Rev. Biol. Trop., 3:165-175.

Williams, NM; EE CRone; TH Roulston; RL MinckleY; L PACKER \& SG POTTS. 2010. Ecological and life-history traits predict bee species responses to environmental disturbances. Biol. Conserv., 143:2280-2291.

WOLINSKI, L. 2012. Partículas en suspensión en lagos andinos, producto de erupciones volcánicas: El zooplanton como bioindicador. Degree Thesis, Univeridad Nacional del Comahue, Argentina.

Wolinski, L; C Laspoumaderes; MB NaVARro; B Modenutti \& E BALSEIRO. 2013. The susceptibility of cladocerans in North Andean Patagonian lakes to volcanic ashes. Freshw. Biol., 58:1878-1888.

Woodrow, RJ; JK Grace; LJ Nelson \& MI Haverty. 2000. Modification of cuticular hydrocarbons of Cryptotermes brevis (Isoptera: Kalotermitidae) in response to temperature and relative humidity. Environ. Entomol., 29:1100-1107.

WOYKe, J \& J GÄBKa. 2011. Effect of volcanic ash cloud over Poland on flight activity of honey bees. J. Apic. Sci., 55:5-17. 


\section{SUPPLEMENTARY INFORMATION}

Appendix 1. Summary of the articles reporting volcanic effects at the individual and population levels of different arthropods. Only studies comparing data with a control situation are included. One article may provide information for several species or have tested different volcanic effects. When available, a quantification of the effect is given between parentheses in the "Volcanic disturbance: effects reported" column, compared with the control situation. The symbol $(\uparrow)$ means higher, $(\downarrow)$ lower, and $(\approx)$ similar. It was indicated whether data were gathered in the laboratory [L] or field [F].

Apéndice 1. Resumen de los artículos que informan efectos volcánicos a niveles individual y poblacional de diferentes artrópodos. Sólo se incluyen los estudios que comparan los datos con una situación control. Un mismo artículo puede proporcionar información para varias especies o haber evaluado diferentes efectos volcánicos. Cuando está disponible, se incluye la cuantificación del efecto entre paréntesis en la columna "Volcanic disturbance: effects reported", en comparación con la situación control. El símbolo $(\uparrow)$ significa superior, $(\downarrow)$ inferior, y $(\approx)$ similar. Se indica si los datos fueron recolectados en el laboratorio [L] o en el campo [F].

\begin{tabular}{|c|c|c|c|c|}
\hline Species & Volcanic disturbance: effects reported & $\begin{array}{l}\text { Type of } \\
\text { comparison }\end{array}$ & Citation & $\begin{array}{l}\text { Volcanic } \\
\text { eruption }\end{array}$ \\
\hline Locustidae sp & $\begin{array}{l}\text { Ash in the environment: no mortality at } \\
\text { high RH, } \uparrow \text { mortality at low RH ( } 2 \text { times) } \\
\text { [L] }\end{array}$ & \multirow{2}{*}{$\begin{array}{l}\text { High }(75 \%) \\
\text { vs low }(55 \%) \\
\text { relative } \\
\text { humidity, with } \\
\text { exposition to ash }\end{array}$} & \multirow[t]{7}{*}{$\begin{array}{l}\text { Wille \& } \\
\text { Fuentes } \\
(1975)\end{array}$} & \multirow[t]{7}{*}{$\begin{array}{l}\text { Irazú, } \\
\text { Costa } \\
\text { Rica }\end{array}$} \\
\hline Diptera, Ceratitis capitata & $\begin{array}{l}\text { Ash on adults: } \uparrow \text { mortality at high and } \\
\text { low relative humidity ( } 7 \text { and } 9 \text { times, } \\
\text { respectively) [L] }\end{array}$ & & & \\
\hline $\begin{array}{l}\text { Hymenoptera, } 1 \text { bee } \\
\text { species }\end{array}$ & Ash in the environment: $\uparrow$ abundance $[\mathrm{F}]$ & \multirow[t]{4}{*}{$\begin{array}{l}\text { Pre vs post } \\
\text { eruption data }\end{array}$} & & \\
\hline $\begin{array}{l}\text { Hymenoptera, } 1 \text { bee } \\
\text { species }\end{array}$ & $\approx$ abundance $[\mathrm{F}]$ & & & \\
\hline $\begin{array}{l}\text { Hymenoptera: } 3 \text { species } \\
\text { of bees }\end{array}$ & $\downarrow$ abundance $[\mathrm{F}]$ & & & \\
\hline $\begin{array}{l}\text { Hymenoptera: } 5 \text { species } \\
\text { of bees and wasps }\end{array}$ & local extinction $[\mathrm{F}]$ & & & \\
\hline $\begin{array}{l}\text { Homoptera, Planococcus } \\
\text { citri }\end{array}$ & Ash in the environment: no effect $[\mathrm{F}]$ & $\begin{array}{l}\text { Colonies on } \\
\text { trees with daily } \\
\text { asperssion of ash }\end{array}$ & & \\
\hline \multirow[t]{2}{*}{$\begin{array}{l}\text { Lepidoptera, Cydia } \\
\text { pomonella }\end{array}$} & $\begin{array}{l}\text { Ash in the environment: } \uparrow \text { adult }(24.8 \%) \\
\text { and larvae mortality }(78 \%) \text {, no ovicidal } \\
\text { nor oviposition deterrent effects [L] }\end{array}$ & $\begin{array}{l}\text { With/out } \\
\text { disturbance }\end{array}$ & \multirow[t]{2}{*}{$\begin{array}{l}\text { Howell } \\
(1981)\end{array}$} & $\begin{array}{l}\text { Mt. St. } \\
\text { Helens, } \\
\text { USA }\end{array}$ \\
\hline & $\begin{array}{l}\text { Ash in the environment: } \approx \text { adult } \\
\text { abundance }[\mathrm{F}]\end{array}$ & $\begin{array}{l}\text { Pre vs post } \\
\text { eruption data }\end{array}$ & & \\
\hline \multirow[t]{3}{*}{$\begin{array}{l}\text { Lepidoptera, Orygia } \\
\text { pseudotsugata }\end{array}$} & $\begin{array}{l}\text { Ash in the environment: } \uparrow \text { mortality in } \\
\text { young }(100 \%) \text { and old larvae }(92 \%)[\mathrm{L}]\end{array}$ & $\begin{array}{l}\text { With/out } \\
\text { disturbance }\end{array}$ & \multirow[t]{3}{*}{$\begin{array}{l}\text { Mason et al. } \\
(1981)\end{array}$} & \\
\hline & $\begin{array}{l}\text { Food contaminated with ash: } 100 \% \\
\text { survival of young and old larvae [L] }\end{array}$ & & & \\
\hline & $\begin{array}{l}\text { Ash in the environment: } \uparrow \text { mortality of } \\
\text { larvae }(98 \%)[\mathrm{F}]\end{array}$ & & & \\
\hline $\begin{array}{l}\text { Hymenoptera , Formica } \\
\text { spp }\end{array}$ & $\begin{array}{l}\text { Ash in the environment: } \approx \text { foraging } \\
\text { activity and food sources, forager ants not } \\
\text { covered by ash; nest size did not change } \\
{[\mathrm{F}]}\end{array}$ & \multirow[t]{3}{*}{$\begin{array}{l}\text { Disturbance } \\
\text { gradient }(0-3 \\
\mathrm{cm})\end{array}$} & \multirow[t]{3}{*}{$\begin{array}{l}\text { Akre et al. } \\
(1981)\end{array}$} & \\
\hline $\begin{array}{l}\text { Hymenoptera, Vespula } \\
\text { spp }\end{array}$ & $\begin{array}{l}\text { Ash in the environment: local extinction in } \\
\text { sites with more than } 3 \mathrm{~cm}[\mathrm{~F}]\end{array}$ & & & \\
\hline $\begin{array}{l}\text { Hymenoptera, } \\
\text { Dolichovespula spp. }\end{array}$ & $\begin{array}{l}\text { Ash in the environment: local extinction } \\
\text { in sites with more than } 3 \mathrm{~cm} \text { of ash, } \\
\text { important reduction in sites with } 1.5 \mathrm{~cm} \\
{[\mathrm{~F}]}\end{array}$ & & & \\
\hline $\begin{array}{l}\text { Orthoptera, Acheta } \\
\text { domesticus }\end{array}$ & $\begin{array}{l}\text { Ash in the environment: } \uparrow \text { water loss; high } \\
\text { mortality }(100 \%) ; 1 \text { st and } 2 \text { nd instars were } \\
\text { more susceptible than adults [L] }\end{array}$ & \multirow[t]{2}{*}{$\begin{array}{l}\text { With/out } \\
\text { disturbance }\end{array}$} & \multirow[t]{2}{*}{$\begin{array}{l}\text { Edwards \& } \\
\text { Schwartz } \\
\text { (1981) }\end{array}$} & \\
\hline $\begin{array}{l}\text { Blatoidea, Periplaneta } \\
\text { americana }\end{array}$ & $\begin{array}{l}\text { Ash in the environment: } \uparrow \text { water loss; high } \\
\text { mortality }(100 \%) \text {, high grooming, ash in } \\
\text { the gut, spiracular valves occluded by ash } \\
\text { but no ash on tracheal trunks [L] }\end{array}$ & & & \\
\hline
\end{tabular}


Appendix 1. Continuation.

Apéndice 1. Continuación.

\begin{tabular}{|c|c|c|c|c|}
\hline Species & Volcanic disturbance: effects reported & $\begin{array}{l}\text { Type of } \\
\text { comparison }\end{array}$ & Citation & $\begin{array}{l}\text { Volcanic } \\
\text { eruption }\end{array}$ \\
\hline \multirow[t]{3}{*}{$\begin{array}{l}\text { Hymenoptera, Apis } \\
\text { mellifera }\end{array}$} & $\begin{array}{l}\text { Ash in the environment: } 10 \% \text { mortality } \\
\text { of colonies, high worker losses, } 5 \text { times } \\
\text { reduction in honey production }[\mathrm{F}]\end{array}$ & $\begin{array}{l}\text { Pre vs post } \\
\text { eruption data }\end{array}$ & \multirow[t]{8}{*}{$\begin{array}{l}\text { Johansen et } \\
\text { al. (1981) }\end{array}$} & \\
\hline & $\begin{array}{l}\text { Ash over brood: } \uparrow \text { larval mortality (84\%) } \\
\text { [L] }\end{array}$ & $\begin{array}{l}\text { Disturbance } \\
\text { gradient }(0-10 \\
\mathrm{mg} / \mathrm{cm} 2)\end{array}$ & & \\
\hline & $\begin{array}{l}\text { Ash in the environment: } 100 \% \text { mortality at } \\
\text { high RH on day } 4,100 \% \text { mortality at low } \\
\text { RH on } 1 \mathrm{~d}[\mathrm{~L}]\end{array}$ & $\begin{array}{l}\text { High }(60 \%) \\
\text { vs low }(20 \%) \\
\text { relative } \\
\text { humidity, with } \\
\text { short exposition } \\
\text { to ash }\end{array}$ & & \\
\hline \multirow[t]{3}{*}{$\begin{array}{l}\text { Hymenoptera, } \\
\text { Megachile rotundata }\end{array}$} & $\begin{array}{l}\text { Ash in the environment: } \downarrow \text { nesting activity } \\
\text { and reproduction }(50 \%)[\mathrm{F}]\end{array}$ & $\begin{array}{l}\text { Pre vs post } \\
\text { eruption data }\end{array}$ & & \\
\hline & $\begin{array}{l}\text { Ash in the environment: } 98 \% \text { and } 29 \% \\
\text { adult mortality without/with refuges, } \\
\text { respectively [L] }\end{array}$ & $\begin{array}{l}\text { With/out } \\
\text { disturbance }\end{array}$ & & \\
\hline & $\begin{array}{l}\text { Ash in the environment: } 0 \% \text { adult } \\
\text { mortality at high } \mathrm{RH} \text { on day } 4,7 \text { times } \\
\text { higher mortality at low } \mathrm{RH} \text { than control } \\
\text { [L] }\end{array}$ & $\begin{array}{l}\text { High vs } \\
\text { low relative } \\
\text { humidity, with } \\
\text { short exposition } \\
\text { to ash }\end{array}$ & & \\
\hline \multirow[t]{2}{*}{$\begin{array}{l}\text { Hymenoptera, Nomia } \\
\text { melanderi }\end{array}$} & $\begin{array}{l}\text { Ash in the environment: nesting activity } \\
\text { not affected }[\mathrm{F}]\end{array}$ & $\begin{array}{l}\text { Pre vs post } \\
\text { eruption data }\end{array}$ & & \\
\hline & $\begin{array}{l}\text { Ash in the environment: } \approx \text { mortality at } \\
\text { high } \mathrm{RH}, \uparrow \text { mortality at low } \mathrm{RH}(2.5 \text { times }) \\
\text { [L] }\end{array}$ & $\begin{array}{l}\text { High }(60 \%) \\
\text { vs low }(20 \%) \\
\text { relative } \\
\text { humidity, with } \\
\text { short exposition } \\
\text { to ash }\end{array}$ & & \\
\hline \multirow[t]{3}{*}{$\begin{array}{l}\text { Coleoptera, Otiorhynchus } \\
\mathrm{sp}\end{array}$} & $\begin{array}{l}\text { Ash in the environment: local extinction } \\
{[\mathrm{F}]}\end{array}$ & $\begin{array}{l}\text { Pre vs post } \\
\text { eruption data }\end{array}$ & \multirow{3}{*}{$\begin{array}{l}\text { Shanks } \\
\text { \& Chase } \\
(1981)\end{array}$} & \\
\hline & $\begin{array}{l}\text { Ash in the environment: } \uparrow \text { mortality (95\%) } \\
\text { [L] }\end{array}$ & $\begin{array}{l}\text { With/out } \\
\text { disturbance }\end{array}$ & & \\
\hline & $\begin{array}{l}\text { Food contaminated with ash: } \uparrow \text { mortality } \\
\text { with food contaminated with ash }(40- \\
80 \%) ; \text { no alimentation [L] }\end{array}$ & $\begin{array}{l}\text { With/out } \\
\text { disturbance }\end{array}$ & & \\
\hline $\begin{array}{l}\text { Plecoptera, Trichoptera, } \\
\text { Ephemeroptera; } 8 \text { species }\end{array}$ & $\begin{array}{l}\text { Ash in the environment: Several } \\
\text { body parts have accumulated ash. No } \\
\text { behavioral differences between insects } \\
\text { exposed to ash [L] }\end{array}$ & $\begin{array}{l}\text { With/out } \\
\text { disturbance }\end{array}$ & $\begin{array}{l}\text { Gersich \& } \\
\text { Brusven } \\
(1982)\end{array}$ & \\
\hline \multirow[t]{2}{*}{$\begin{array}{l}\text { Homoptera, Psylla } \\
\text { pyricola }\end{array}$} & $\begin{array}{l}\text { Ash in the environment: } \downarrow \text { oviposition } \\
\text { (85\%), } \uparrow \text { egg and nymph mortality (73\%- } \\
79 \% \text {, whole and fine ash), } \downarrow \text { adult survival } \\
\text { (54\%) [L] }\end{array}$ & $\begin{array}{l}\text { with/out } \\
\text { disturbance; fine } \\
\text { (sieved)/whole }\end{array}$ & Fye (1983) & \\
\hline & $\begin{array}{l}\text { Ash in the environment: } \uparrow \text { abundance in } \\
\text { low ash orchard; } \downarrow \text { abundance }(75 \%) \text { with } \\
\text { intermediate and high ashfall. Population } \\
\text { recovered } 1 \text { yr after [F] }\end{array}$ & $\begin{array}{l}\text { Pre vs post } \\
\text { eruption data; } \\
\text { ashfall gradient }\end{array}$ & & \\
\hline $\begin{array}{l}\text { Hemipetera, Deraeocoris } \\
\text { brevis }\end{array}$ & $\begin{array}{l}\text { Ash in the environment: No change with } \\
\text { low ash, } \downarrow \text { abundance. Recovered } 1 \text { yr } \\
\text { after }[\mathrm{F}]\end{array}$ & & & \\
\hline $\begin{array}{l}\text { Hemipetera, Anthocoris } \\
\text { melanocerus }\end{array}$ & $\begin{array}{l}\text { Ash in the environment: Eliminated from } \\
\text { intermediate and high ashfall. After } 1 \mathrm{yr} \\
\text { population were not recovered }[\mathrm{F}]\end{array}$ & & & \\
\hline
\end{tabular}


Appendix 1. Continuation.

Apéndice 1. Continuación.

\begin{tabular}{|c|c|c|c|c|}
\hline Species & Volcanic disturbance: effects reported & $\begin{array}{l}\text { Type of } \\
\text { comparison }\end{array}$ & Citation & $\begin{array}{l}\text { Volcanic } \\
\text { eruption }\end{array}$ \\
\hline \multirow[t]{2}{*}{$\begin{array}{l}\text { Plecoptera, Trichoptera, } \\
\text { Ephemeroptera; } 10 \\
\text { species }\end{array}$} & $\begin{array}{l}\text { Ash in the stream bed: preference for } \\
\text { conditions without ash [L] }\end{array}$ & $\begin{array}{l}\text { With/out } \\
\text { disturbance }\end{array}$ & $\begin{array}{l}\text { Brusven } \\
\text { \& Horing } \\
(1984)\end{array}$ & \\
\hline & $\begin{array}{l}\text { Ash suspended in the water column: } \uparrow \\
\text { mortality for some species, } \approx \text { for others; } \\
\text { no differential effect of ash on different } \\
\text { instars [L] }\end{array}$ & $\begin{array}{l}\text { With/out } \\
\text { disturbance }\end{array}$ & & \\
\hline $\begin{array}{l}\text { Coleoptera, Oryzaephilus } \\
\text { surinamensis }\end{array}$ & $\begin{array}{l}\text { Ash in the environment: adult lethal } \\
\text { concentration: } 10.25 \mathrm{mg} \cdot \mathrm{g}-1 \text { [L] }\end{array}$ & $\begin{array}{l}\text { With/out } \\
\text { disturbance }\end{array}$ & $\begin{array}{l}\text { Buteler et } \\
\text { al. (2011) }\end{array}$ & $\begin{array}{l}\text { Puyehue- } \\
\text { Cordón } \\
\text { Caulle, } \\
\text { Chile }\end{array}$ \\
\hline $\begin{array}{l}\text { Coleoptera, Tribolium } \\
\text { castaneum }\end{array}$ & $\begin{array}{l}\text { Ash in the environment: adult lethal } \\
\text { concentration: } 4.96 \mathrm{mg} \cdot \mathrm{g}-1 \text { [L] }\end{array}$ & & & \\
\hline $\begin{array}{l}\text { Hymenoptera, Vespula } \\
\text { germanica; } V \text {. vulgaris }\end{array}$ & $\begin{array}{l}\text { Ash in the environment: local extinction } \\
>3 \mathrm{~cm}, \downarrow \text { abundance } 0.2-3 \mathrm{~cm} \text { of } \\
\text { accumulated ash; } \approx \text { abundance } 0-0.2 \mathrm{~cm} \\
\text { of ash }[\mathrm{F}]\end{array}$ & $\begin{array}{l}\text { Ashfall gradient } \\
(0-30 \mathrm{~cm})\end{array}$ & $\begin{array}{l}\text { Masciocchi } \\
\text { et al. (2012) }\end{array}$ & \\
\hline \multirow[t]{2}{*}{$\begin{array}{l}\text { Hymenoptera, Apis } \\
\text { mellifera }\end{array}$} & $\begin{array}{l}\text { Ash in the environment: } \downarrow \text { flower visit } \\
\text { rates; increase in reflectivity in ash- } \\
\text { contaminated flowers [F] }\end{array}$ & $\begin{array}{l}\text { With/out } \\
\text { disturbance }\end{array}$ & $\begin{array}{l}\text { Martínez et } \\
\text { al. (2013) }\end{array}$ & \\
\hline & $\begin{array}{l}\text { Food contaminated with ash: } \approx \\
\text { consumption rates; } \downarrow \text { survival for } \\
\text { contaminated water and sugar }(50 \%), \text { no } \\
\text { effect on survival for contaminated pollen } \\
{[\mathrm{F}]}\end{array}$ & $\begin{array}{l}\text { With/out } \\
\text { disturbance }\end{array}$ & & \\
\hline $\begin{array}{l}\text { Cladocera, Daphnia } \\
\text { commutata }\end{array}$ & $\begin{array}{l}\text { Ash suspended in the water column: } \downarrow \\
\text { survival and reproduction with increased } \\
\text { ash concentration [L] }\end{array}$ & $\begin{array}{l}\text { With disturbance } \\
\text { gradient }\end{array}$ & $\begin{array}{l}\text { Wolinsky et } \\
\text { al. (2013) }\end{array}$ & \\
\hline $\begin{array}{l}\text { Cladocera, Ceriodaphnia } \\
\text { dubia }\end{array}$ & $\begin{array}{l}\text { Ash in the lake bed: local extinction } \\
\text { during eruption; } 8 \text { mo after population } \\
\text { was recovering }[\mathrm{F}]\end{array}$ & $\begin{array}{l}\text { Pre vs post } \\
\text { eruption data, } \\
\text { disturbance }\end{array}$ & & \\
\hline $\begin{array}{l}\text { Copepoda, Boeckella } \\
\text { gracilipes }\end{array}$ & $\begin{array}{l}\text { Ash in the lake bed: } \downarrow \text { abundance in } \\
\text { most disturbed lake, no change in less } \\
\text { disturbed lakes [F] }\end{array}$ & gradient & & \\
\hline \multirow[t]{2}{*}{$\begin{array}{l}\text { Orthoptera, Dichroplus } \\
\text { vittigerum }\end{array}$} & $\begin{array}{l}\text { Ash in the environment: } \uparrow \text { mortality at } \\
\text { high and low RH more food consumed at } \\
\text { low RH [L] }\end{array}$ & $\begin{array}{l}\text { Adults exposed } \\
\text { to ash }(0.5 \mathrm{~g}) \text { at } \\
\text { high }(75 \% \mathrm{RH}) \\
\text { and ambient } \\
\text { humidity }(40 \% \\
\text { RH) }\end{array}$ & $\begin{array}{l}\text { Fernández- } \\
\text { Arhex et al. } \\
\text { (2013) }\end{array}$ & \\
\hline & Ash suspended in the air: $\downarrow$ survival [L] & $\begin{array}{l}\text { With/out } \\
\text { disturbance }\end{array}$ & & \\
\hline
\end{tabular}


Appendix 2. Summary of the articles reporting volcanic effects at community levels of different arthropods. Only studies that compared information with a control situation are included. See Appendix 1 for description of symbols in the "Volcanic disturbance: effects reported" column.

Apéndice 2. Resumen de los artículos que informan efectos volcánicos a nivel comunidad de diferentes artrópodos. Sólo se incluyen los estudios que comparan la información con una situación control. Ver Apéndice 1 para la descripción de los símbolos de la columna "Volcanic disturbance: effects reported".

\begin{tabular}{|c|c|c|c|c|}
\hline Arthropod taxa & Volcanic disturbance: effects reported & $\begin{array}{l}\text { Type of } \\
\text { comparison }\end{array}$ & Citation & $\begin{array}{l}\text { Volcanic } \\
\text { eruption }\end{array}$ \\
\hline $\begin{array}{l}\text { Trichoptera, } \\
\text { benthic species }\end{array}$ & $\begin{array}{l}\text { Ashfall on streams: } \approx \text { species richness; } \\
\downarrow \text { abundance in scraping and collector } \\
\text { filter species after } 2 \text { mo, rapid recovery in } \\
\text { most species after } 4 \text { mo }\end{array}$ & $\begin{array}{l}\text { With/out } \\
\text { disturbance (c. } 15 \\
\text { cm ashfall) }\end{array}$ & Smith (1981) & $\begin{array}{l}\text { Mt. St. Helens, } \\
\text { USA }\end{array}$ \\
\hline $\begin{array}{l}\text { Arthropods, } \\
\text { several spp }\end{array}$ & $\begin{array}{l}\text { Ashfall in wheat cropland: } \approx \text { taxa } \\
\text { richness; } \downarrow \text { abundance in some taxa; } \uparrow \\
\text { abundance in others }\end{array}$ & $\begin{array}{l}\text { Pre vs post } \\
\text { eruption data ( } 2 \\
\mathrm{~cm} \text { ashfall) }\end{array}$ & $\begin{array}{l}\text { Klostermeyer } \\
(1981)\end{array}$ & \\
\hline $\begin{array}{l}\text { Coleoptera, several } \\
\text { spp }\end{array}$ & $\begin{array}{l}\text { Lava, tree blowdown, tephra fall: } \\
\text { changes in community composition, } \\
\text { dependent on disturbance type and } \\
\text { along time }\end{array}$ & $\begin{array}{l}\text { Disturbance } \\
\text { gradient }\end{array}$ & $\begin{array}{l}\text { Parmenter et } \\
\text { al. (2005) }\end{array}$ & \\
\hline $\begin{array}{l}\text { Insecta, several } \\
\text { benthic species }\end{array}$ & $\begin{array}{l}\text { Acidic lahar on river (tephra): no changes } \\
\text { in community composition }\end{array}$ & $\begin{array}{l}\text { Pre vs post } \\
\text { eruption data }\end{array}$ & Collier (2002) & $\begin{array}{l}\text { Mt Ruapehu, } \\
\text { New Zealand }\end{array}$ \\
\hline $\begin{array}{l}\text { Canopy insects, } \\
\text { several orders }\end{array}$ & $\begin{array}{l}\text { Ashfall accumulated on tree leaves: } \downarrow \\
\text { abundance (40\%), especially Psocoptera, } \\
\text { Coleoptera, Formicidae }\end{array}$ & $\begin{array}{l}\text { Disturbance } \\
\text { gradient (from } 0 \\
\text { to } 5,000 \mathrm{mg} / \mathrm{m} 2 \\
\text { of ash) }\end{array}$ & $\begin{array}{l}\text { Marske et al. } \\
\text { (2007) }\end{array}$ & $\begin{array}{l}\text { Soufrière Hills, } \\
\text { Montserrat }\end{array}$ \\
\hline $\begin{array}{l}\text { Insecta, several } \\
\text { spp }\end{array}$ & $\begin{array}{l}\text { Pyroclastic flow and tephra: } \downarrow \text { species } \\
\text { richness (nine times) }\end{array}$ & $\begin{array}{l}\text { Pre vs post } \\
\text { eruption data }\end{array}$ & $\begin{array}{l}\text { Sikes \& } \\
\text { Slowik (2010) }\end{array}$ & $\begin{array}{l}\text { Kasatochi, } \\
\text { Alaska }\end{array}$ \\
\hline Arthropods & $\begin{array}{l}\text { Lava flow, tephra fall: changes in } \\
\text { community composition (reduction of } \\
\text { native species, particularly endemic, and } \\
\text { increase in exotic species) and species } \\
\text { richness. }\end{array}$ & $\begin{array}{l}\text { Disturbance } \\
\text { gradient }\end{array}$ & $\begin{array}{l}\text { Fattorini \& } \\
\text { Borges (2012) }\end{array}$ & $\begin{array}{l}\text { Capelinhos, } \\
\text { Azores, } \\
\text { Portugal }\end{array}$ \\
\hline $\begin{array}{l}\text { Macroinvertebrate } \\
\text { (insects) benthic } \\
\text { species }\end{array}$ & $\begin{array}{l}\text { Ashfall on river: } \downarrow \text { species richness (20- } \\
40 \%) ; \downarrow \text { abundance }\end{array}$ & $\begin{array}{l}\text { Pre vs post } \\
\text { eruption data ( } 3 \\
\text { to } 10 \mathrm{~mm} \text { ashfall })\end{array}$ & $\begin{array}{l}\text { Miserendino } \\
\text { et al (2012) }\end{array}$ & Chaitén, Chile \\
\hline
\end{tabular}

References (only those not included in the main text).

COLLIER, KJ. 2002. Effects of flow regulation and sediment flushing on instream habitat and benthic invertebrates in a New Zealand river influenced by a volcanic eruption. River. Res. Appl., 18:213-226.
FYE, RE. 1983. Impact of volcanic ash on pear psylla (Homoptera: Psyllidae) and associated predators. Environ. Entomol., 12:222-226.

SMITH, SD.1981. Preliminary report effects of Mt. St. Helens ashfall on lotic Trichoptera. Melanderia, 37:56-62. 